10. Reyes ZC, Claure N, Tauscher MK, D'Ugard C, Vanbuskirk S, Bancalari E. Randomized, controlled trial comparing synchronized intermittent mandatory ventilation and synchronized intermittent mandatory ventilation plus pressure support in preterm infants . Pediatrics. 2006;118:1409-17.

11. Greenough A, Milner AD, Dimitriou G. Synchronized mechanical ventilation for respiratory support in newborn infants. Cochrane Database Syst Rev. 2004;(3):CD000456.
Correspondence:

Professor Anne Greenough

Regional Neonatal Intensive Care Centre

4th Floor Golden Jubilee Wing

King's College Hospital, Denmark Hill

London, SE5 9RS, United Kingdom

Tel.: +44 (20) 3299.3037

Fax: +44 (20) 3299.8284

E-mail: anne.greenough@kcl.ac.uk

\title{
Diarrhea mortality: what can the world learn from Brazil?
}

\section{Cesar G. Victora*}

Every year, nearly 2 million children all over the world die from diarrhea. In most poor countries, diarrhea is the third most common cause of death of children under 5 years of age, just after neonatal causes and pneumonia. ${ }^{1}$ The annual number of diarrhea deaths worldwide is about the same as that of AIDS deaths at any age - currently estimated at 2.1 million. ${ }^{2}$ Yet, diarrhea attracts much less attention than HIV/AIDS or other currently fashionable diseases such as malaria, that accounts for about 1.3 million deaths a year, at all ages.

In this issue of the Jornal de Pediatria, Melli \& Waldman ${ }^{3}$ use routine data from a Brazilian municipality in the São Paulo metropolitan area to examine recent trends in diarrhea mortality. A strength of their paper is to show how much may be inferred from the judicious use of routine statistical information in an area of southeastern Brazil where vital registration has been complete - or nearly so - for the last few decades.

Their first striking finding is the remarkable drop in diarrhea mortality rates among infants, from 11.9 to 0.2 deaths per 1,000 live births, a 98.6\% reduction between 1980 and 2000. Proportionate mortality data for Brazil as a whole confirm this major decline. Diarrhea was responsible for $17.3 \%$ of all registered infant deaths in 1985-1987, ${ }^{4}$ and by 2003-2005 (the latest year with information) it accounted for $4.2 \%$ of all deaths. ${ }^{5}$ If we take into account that all-cause infant mortality rates for Brazil also dropped from about 60 to just over 20 per 1,000 live births in the same period, the reduction in diarrhea mortality rates per 1,000 live births was roughly $90 \%$. Further support is provided by our studies in
Pelotas, southern Brazil, where the infant mortality rate due to diarrhea fell from 4.2 in 1982 to 0.2 per 1,000 live births in $2004 .{ }^{6}$ Anyone who has worked with child health in Brazil knows that these declines are real. Hospital admissions due to diarrhea have also dropped markedly in the poorest parts of the country, ${ }^{7}$ and it is now difficult, if not impossible, to teach our medical students the signs of acute dehydration in children, which once used to be a common finding in our outpatient and emergency services.

Melli \& Waldman ${ }^{3}$ also report changes in the seasonality of diarrhea, with a marked summer peak associated with bacterial episodes being replaced by a modest peak in the fall, which as the authors argue is likely due to improved sanitation reducing fecal-oral transmission.

However, the most interesting aspect of their analyses of diarrhea deaths is the documentation of reduced geographical disparities, which reflect a decline in socioeconomic inequities. A reduction in the absolute level of a disease is not always associated with a reduction in inequalities - often the opposite seems to occur. ${ }^{8}$ Fortunately, this was not the case in Osasco, state of São Paulo, where the marked decline in mortality led to the virtual disappearance of the geographical disparities. Obviously, if a disease is completely eradicated such as smallpox, polio or measles in Brazil -, social inequalities will disappear as well. This seems to be happening with diarrhea in Osasco.

* Graduate Program in Epidemiology, Universidade Federal de Pelotas (UFPel), Pelotas, RS, Brazil.

No conflicts of interest declared concerning the publication of this editorial.

Suggested citation: Victora CG. Diarrhea mortality: what can the world learn from Brazil? J Pediatr (Rio J). 2009;85(1):3-5.

doi:10.2223/JPED. 1860 
Their finding reminded me of an analysis of the decline in mortality due to diarrhea in children under 2 years of age living in Stockholm, Sweden, between 1878 and $1925 .^{9}$ Diarrhea mortality declined from 59 to 2 per 1,000 live births, and social inequalities practically disappeared - at a very different time and place, the Brazilian and Swedish studies show similar results.

Because their analyses are based on secondary data, the authors can only speculate about potential reasons for the decline in diarrhea mortality in Osasco. They did so through examining which among the known determinants of diarrhea mortality have changed in the 20-year period under study. Based on such time trend data, they argue that improved water and sanitation, increased duration of exclusive and total breastfeeding, reduced prevalence of undernutrition, and improved access to health care with use of oral rehydration are all likely to have played a role. In an analysis of diarrhea mortality trends that we performed for northeastern Brazil, including mathematical simulations of the effects of change in several risk factors, we concluded that the major factor responsible for the decline is likely to have been increased coverage with health care - particularly the use of oral rehydration therapy -, although improved water and sanitation, increased breastfeeding and measles vaccination seem to also have played a role. ${ }^{7}$

We will now get back to the diarrhea deaths that kill 1.9 million children under 5 years of age, every single year, particularly in sub-Saharan Africa and in South Asia. ${ }^{10}$ What can the Brazilian successful story teach them?

First, we started with very intense and successful campaigns for oral rehydration therapy in the 1980 s with the participation of the Brazilian Ministry of Health, the Brazilian Society of Pediatrics, the Pastoral da Criança (a very active non-governmental organization linked to the Catholic Church), UNICEF and the Pan American Health Organization, among others. This campaign promoted activities at the level of health facilities but also at the community level. It could be described as a "vertical" campaign to a large extent, because it had its own structure from the central level in Brasília, the capital of Brazil, to the community level.

Second, there were important improvements in water and sanitation over time, as well as a general process of economic development that has reduced the levels of absolute poverty in our country. After decades in which income inequalities in Brazil were getting wider and wider, we have seen a gradual decline in the Gini coefficient for income concentration - from 0.64 in 1991 to 0.55 in 2006; this still represents a wide gap between rich and poor, but the improvement is not negligible. ${ }^{11}$

Finally, with the launching of the Brazilian National Health System (Sistema Único de Saúde, SUS) 20 years ago, and in particular of the Family Health Strategy in 1994, access to primary health care has increased substantially. The latter strategy was effectively targeted at poor municipalities and poor neighborhoods in urban areas, e.g. urban favelas. ${ }^{12,13} \mathrm{Sev}-$ eral ecological analyses suggest that the program had a positive impact on infant mortality, ${ }^{13,14}$ particularly through reduction of diarrhea deaths. ${ }^{15}$

In my view, Brazil has much to teach to countries where childhood diarrhea is still a major killer of young children. We started with vertical programs: the 1980 s campaigns raised awareness that diarrhea a) was an important public health problem and b) could be managed effectively with oral rehydration. Vertical programs may have short-term impact but are unlikely to be sustainable unless they are incorporated within a broader health strategy. Our longer-term, "horizontal" approaches promoting universal primary health care, combined with improved water and sanitation, have ensured that the short-term gains from the 1980s campaigns were maintained and improved upon. A similar experience took place in Mexico, where the term "diagonal approach" was proposed to describe the combination of both types of strategies. ${ }^{16}$

The fourth Millennium Development Goal is to reduce by $2 / 3$ the mortality of children under 5 years of age from 1990 to $2015 .{ }^{1}$ To reach this goal, the prevailing response by the international community - including the United Nations and donor country organizations - has been to promote vertical campaigns. For diarrhea deaths, oral rehydration, vitamin A supplementation and measles vaccination (because of the known comorbidity between measles and diarrhea) are the key elements of such campaigns, which are aimed at preventing deaths in the short term. This is commendable, but unless the vertical approach is followed by a building up of health systems, gains could be short-lived.

The Swedish study ends with a piece of wisdom: "in spite of the powerful interventions and action that took place, the decline of diarrhea mortality in Stockholm took quite some time; this demonstrates the need for patience when evaluating large-scale intervention projects in poor countries today." This is indeed what the experience from Osasco, and from Brazil as a whole, is once again demonstrating.

\section{References}

1. The United Nations Children's Fund (UNICEF). Countdown to 2015: maternal, newborn and child survival. Tracking progress in maternal, neonatal and child survival: the 2008 report. New York, NY: UNICEF; 2008.

2. World Health Organization (WHO). Joint United Nations Programme on HIV/AIDS (UNAIDS). AIDS Epidemic Update June 2008. Geneva: UNAIDS/WHO; 2008.

3. Melli LC, Waldman EA. Temporal trends and inequality in under-5 mortality from diarrhea. J Pediatr (Rio J). 2009;85:21-27. 
4. Victora CG. Intervenções para reduzir a mortalidade infantil, pré-escolar e materna no Brasil. Rev Bras Epidemiol. 2001; 4:3-69.

5. Brasil. Ministério da Saúde. Indicadores de mortalidade: C.6 Mortalidade proporcional por doença diarreica aguda em menores de 5 anos de idade. http://tabnet.datasus.gov.br/cgi/ deftohtm.exe?idb2007/c06.def. Access: 10.11.2008.

6. Santos IS, Menezes AM, Mota DM, Albernaz EP, Barros AJ, Matijasevich $A$, et al. Infant mortality in three population-based cohorts in Southern Brazil: trends and differentials . Cad Saude Publica. 2008;24 Suppl 3: 451-60.

7. Victora CG, Olinto MT, Barros FC, Nobre LC. Falling diarrhoea mortality in Northeastern Brazil: did ORT play a role? Health Policy Plan. 1996;11:132-41.

8. Gwatkin, D.R., How much would poor people gain from faster progress towards the Millennium Development Goals for health? Lancet. 2005;365:813-7.

9. Burström B, Macassa G, Oberg L, Bernhardt E, Smedman L. Equitable child health interventions: the impact of improved water and sanitation on inequalities in child mortality in Stockholm, 1878 to 1925 . Am J Public Health. 2005;95:208-16.

10. Black RE, Morris SS, Bryce J. Where and why are 10 million children dying every year? Lancet. 2003;361:2226-34.

11. Comissão Nacional sobre Determinantes Sociais da Saúde. As causas sociais das iniqüidades em saúde no Brasil: relatório final da Comissão Nacional sobre Determinantes sociais da saúde. Rio de Janeiro, RJ: Fiocruz; 2008.
12. Barros AJ, Victora CG, Cesar JA, Neumann NA, Bertoldi AD. Brazil: are health and nutrition programs reaching the neediest? In: Gwatkin DR, Wagstaff A, Yazbeck AS, editors. Reaching the poor with health, nutrition and population services: what works, what doesn't and why. Washington, DC: World Bank; 2005. p. 281-306. http://siteresources.worldbank.org/INTPAH/ Resources/Reaching-the-Poor/complete.pdf . Access: 10.11.2008.

13. Pereira RA. Programa de Saúde da Família: determinantes e efeitos de sua implantação nos municípios brasileiros [Tese]. Salvador, BA: Universidade Federal da Bahia; 2006.

14. Macinko J, Marinho de Souza Mde F, Guanais FC, da Silva Simões CC. Going to scale with community-based primary care: An analysis of the family health program and infant mortality in Brazil, 1999-2004 . Soc Sci Med. 2007;65:2070-80.

15. Macinko J, Guanais FC, de Fátima M, de Souza M. Evaluation of the impact of the Family Health Program on infant mortality in Brazil, 1990-2002. J Epidemiol Community Health. 2006;60: 13-9.

16. Sepúlveda J, Bustreo F, Tapia R, Rivera J, Lozano R, Oláiz G, et al. Improvement of child survival in Mexico: the diagonal approach . Lancet. 2006;368:2017-27.

Correspondence:

Cesar G. Victora

E-mail: cvictora@terra.com.br 